\title{
An exploration study to detect important factors influencing customer relationship management on reducing unhappy clients
}

\author{
Zeynab Davand and Somayeh Hozouri*
}

Department of Management, Islamic Azad University, South Tehran Branch, Tehran, Iran

\begin{tabular}{|c|c|}
\hline CHRON I CLE & A B S T RACT \\
\hline $\begin{array}{l}\text { Article history: } \\
\text { Received May 12, } 2013 \\
\text { Received in revised format } \\
12 \text { August } 2013 \\
\text { Accepted } 28 \text { September } 2013 \\
\text { Available online } \\
\text { October } 10 \text { 2013 } \\
\text { Keywords: } \\
\text { Customer loyalty } \\
\text { Customer relationship } \\
\text { management } \\
\text { Marketing planning }\end{array}$ & $\begin{array}{l}\text { This paper presents an investigation to find out important factors influencing } \\
\text { electronic customer relationship management on reducing customer complaints. The } \\
\text { proposed study designs a questionnaire in Likert scale consists of } 19 \text { questions, } \\
\text { distributes it among some Iranian experts in banking industry and analyzes it based on } \\
\text { principal component analysis. During the survey, the number questions are reduced to } \\
16 \text { because of skewness of three questions. Cronbach alpha is calculated as } 0.82 \text { and } \\
\text { Kaiser-Meyer-Olkin Measure of Sampling Adequacy and Approx. Chi-Square are } \\
0.746 \text { and 1993, respectively. Based on the results of our survey, we have derived four } \\
\text { factors including knowledge management, customer retention, customer oriented } \\
\text { strategy and structure oriented. }\end{array}$ \\
\hline
\end{tabular}

\section{Introduction}

During the past few years, there have been tremendous changes on electronic marketing and many people prefer to make their purchase through online trading (Aaker, 2010; Stiglitz \& Weiss 1981). The success of offering goods and services through internet has been very huge and there are many big-cap firms such as AMAZON, E-bay, etc. whose shares are among most popular companies on US stock exchange (Leuthesser et al., 2011). These days, when a customer purchases a good through internet, a survey has been accomplished to receive customer's feedback on goods and services sold (Franco, 1990). E-business has become an important business and customer retention plays essential role on the success of business units (Hsieh \& Li, 2011; Stigler, 1961). Sivaraks et al. (2011) investigated the outcomes of electronic customer relationship management (e-CRM) system

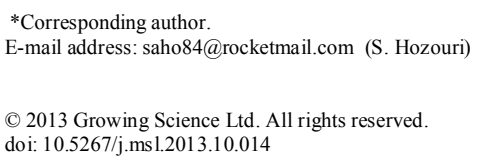


implementation in the Thai banking industry from customers' perspectives (Kimiloglu \& Zarali, 2009).

They discussed that most e-CRM implementations could not be directly observed or recognised by customers and they performed a literature review and interviewed with experts in the Thai banking industry to develop a new construct called 'customer-based service attributes' to measure e-CRM outcomes from customers' perspectives. They performed structural equation modelling (SEM) and reported that e-CRM implementation had a statistically significant positive relationship with customer-based service attributes and with the quality and outcome of customer-bank relationships as well as an indirect impact on relationship quality and outcome through customer-based service attributes.

Romano and Fjermestad (2003) studied e-CRM, presented a conceptual framework to study the relationships among and between different areas within e-CRM, and proposed how they might be integrated to further research this area. They started with a discussion of each of the research areas through brief reviews of relevant literature for each and a discussion of the theoretical and strategic implications related to some CRM technologies and research areas. They also presented a theoretical framework for e-CRM in terms of the five research areas and how they influenced one another, as well as e-CRM processes and both performance and non-performance outcomes.

Ahmad and Rashid (2012) analyzed current banking practices in Pakistan, regarding the e-CRM. The primary objective was to explore the variables in association with operational problems, which could happen with banks that applied e-CRM and the customer's perception of the usage of e-banking. They provided some ideas and practical suggestions, which could be implemented, particularly with Ebanking to improve its continuance.

Lee-Kelley et al. (2003) provided some evidences of how to improve planning for customer management by presenting and testing a conceptual model of the process by which the implementation of e-CRM, can enhance loyalty. Luck and Lancaster (2003) explored the degree to which UK based hotel groups had exploited the medium of e-CRM. They reported that the majority of the hotel groups had only embraced a few elements of E-CRM and even reported that they had no intention of being led online by the concept. Although the results of their questionnaire implied that hotel groups were generally aware of the potential of Web technologies and strategies, their results also demonstrated that firms were not putting this knowledge into practice when it came to implementing E-CRM. They reported that hotel groups based in the UK were failing to take advantage of the many opportunities identified through the secondary research.

\section{The proposed study}

This paper presents an investigation to find out important factors influencing electronic customer relationship management on reducing customer complaints. The proposed study designs a questionnaire in Likert scale consists of 19 questions, distributes it among some Iranian experts in banking industry and analyzes it based on principal component analysis. During the survey, the number questions are reduced to 16 because of skewness of three questions. Cronbach alpha is calculated as 0.82 and Kaiser-Meyer-Olkin Measure of Sampling Adequacy and Approx. Chi-Square are 0.746 and 1993, respectively. Table 1 summarizes the results of our survey on communalities. Fig. 1 demonstrates the results of Scree plot. As we can observe from the results of Fig. 1, there are four factors, which could be extracted for further studies. In addition, as we can observe from the results of communalities given in Table 1, most factors are well above the minimum acceptable level of 0.5 . Table 2 demonstrates the results of factor analysis on these factors. 


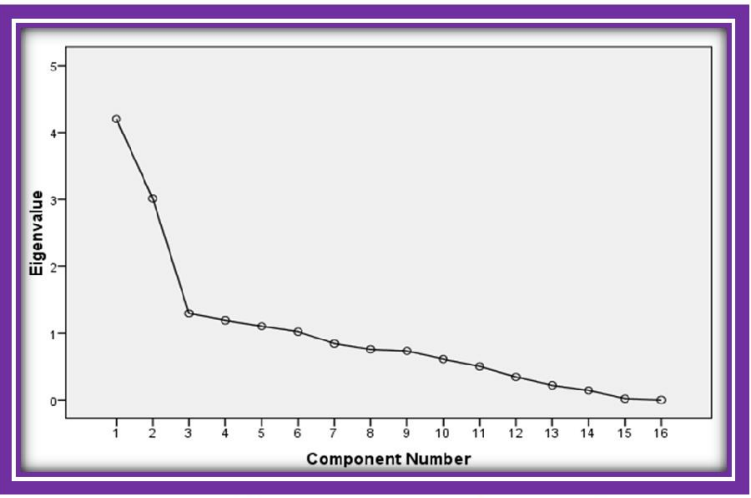

Fig. 1. The summary of Scree plot

\section{Table 1}

The summary of communalities

\begin{tabular}{|c|c|c|}
\hline & $\begin{array}{c}\text { Communalities } \\
\text { Initial }\end{array}$ & Extraction \\
\hline VAR00001 & 1.000 & .611 \\
\hline VAR00002 & 1.000 & .684 \\
\hline VAR00003 & 1.000 & .719 \\
\hline VAR00005 & 1.000 & .652 \\
\hline VAR00006 & 1.000 & .667 \\
\hline VAR00007 & 1.000 & .540 \\
\hline VAR00009 & 1.000 & .734 \\
\hline VAR00010 & 1.000 & .636 \\
\hline VAR00011 & 1.000 & .924 \\
\hline VAR00012 & 1.000 & .838 \\
\hline VAR00013 & 1.000 & .674 \\
\hline VAR00014 & 1.000 & .935 \\
\hline VAR00015 & 1.000 & .920 \\
\hline VAR00016 & 1.000 & .924 \\
\hline VAR00017 & 1.000 & .801 \\
\hline VAR00019 & 1.000 & .569 \\
\hline
\end{tabular}

Table 2

The summary of principal component analysis after rotation

\begin{tabular}{|c|c|c|c|c|c|c|c|c|c|}
\hline \multirow[t]{2}{*}{ Component } & \multicolumn{3}{|c|}{ Initial Eigenvalues } & \multicolumn{3}{|c|}{ Extraction Sums of Squared } & \multicolumn{3}{|c|}{ Rotation Sums of Squared } \\
\hline & Total & $\%$ of Variance & $\begin{array}{c}\text { Cumulative } \\
\%\end{array}$ & Total & $\begin{array}{c}\% \text { of } \\
\text { Variance }\end{array}$ & $\begin{array}{c}\text { Cumulative } \\
\%\end{array}$ & Total & $\begin{array}{r}\% \text { of } \\
\text { Variance }\end{array}$ & $\begin{array}{r}\text { Cumulative } \\
\%\end{array}$ \\
\hline 1 & 4.204 & 26.275 & 26.275 & 4.204 & 26.275 & 26.275 & 3.941 & 24.633 & 24.633 \\
\hline 2 & 3.013 & 18.834 & 45.109 & 3.013 & 18.834 & 45.109 & 3.095 & 19.346 & 43.980 \\
\hline 3 & 1.294 & 8.090 & 53.199 & 1.294 & 8.090 & 53.199 & 1.271 & 7.944 & 51.923 \\
\hline 4 & 1.191 & 7.443 & 60.642 & 1.191 & 7.443 & 60.642 & 1.192 & 7.447 & 59.371 \\
\hline 5 & 1.104 & 6.900 & 67.542 & 1.104 & 6.900 & 67.542 & 1.172 & 7.324 & 66.695 \\
\hline 6 & 1.021 & 6.381 & 73.923 & 1.021 & 6.381 & 73.923 & 1.156 & 7.228 & 73.923 \\
\hline 7 & .844 & 5.273 & 79.196 & & & & & & \\
\hline 8 & .758 & 4.737 & 83.933 & & & & & & \\
\hline 9 & .734 & 4.586 & 88.519 & & & & & & \\
\hline 10 & .612 & 3.822 & 92.341 & & & & & & \\
\hline 11 & .502 & 3.139 & 95.480 & & & & & & \\
\hline 12 & .344 & 2.152 & 97.632 & & & & & & \\
\hline 13 & .218 & 1.361 & 98.993 & & & & & & \\
\hline 14 & .142 & .887 & 99.879 & & & & & & \\
\hline 15 & .019 & .121 & 100.000 & & & & & & \\
\hline 16 & .844 & 5.273 & 100.000 & & & & & & \\
\hline
\end{tabular}

Based on the results of our survey, we have derived four factors including knowledge management, customer retention, customer oriented strategy and structure oriented. 


\section{The results}

In this section, we present details of our findings on four influencing factors.

\subsection{The first factor: Knowledge Management}

The first factor is associated with knowledge management. Table 3 demonstrates details of our survey. As we can observe from the results of Table 3, "Update information" is the most important factor, followed by "Innovation and learning outlook", "Update information", "Digital customer's perception" and "Communication channels".

\section{Table 3}

The summary of factors associated with knowledge management

\begin{tabular}{llccc}
\hline Option & Factor weight & Eigenvalues & \% of variance & Accumulated \\
\hline Update information & .674 & & & \\
Digital customer's perception & .621 & & & \\
Knowledge management & .733 & 1.479 & 36.972 & 36.972 \\
Communication channels & .506 & & \\
Innovation and learning outlook & .674 & & \\
\hline Cronbach alpha $=0.70$ & & &
\end{tabular}

\subsection{The second factor: Customer retention}

Customer retention is the second important factor and it includes four factors, which are summarized in Table 4 as follows,

\section{Table 4}

The summary of factors associated with customer retention

\begin{tabular}{llccc}
\hline \multicolumn{1}{c}{ Option } & Factor weight & eigenvalues & \% of variance & Accumulated \\
\hline Trust and support & .690 & 1.326 & 26.512 & 26.512 \\
Commitment & .585 & & & \\
Customer's requirements perception & .630 & & & \\
Management of customer information & .524 & & & \\
\hline Cronbach alpha $=0.680$ & & & & \\
\hline
\end{tabular}

According to the results of Table 4, "trust and support" is number one priority followed by "customer's requirements perception", "Commitment" and "Management of customer information".

\subsection{The third factor: Customer oriented strategy}

Customer oriented strategy is another important factor with three items summarized in Table 5.

\section{Table 5}

The summary of factors associated with customer oriented strategy

\begin{tabular}{lcccc}
\hline \multicolumn{1}{c}{ Option } & Factor weight & eigenvalues & \% of variance & Accumulated \\
\hline Customer value & .854 & 1.640 & 54.675 & 54.675 \\
Information services & .684 & & & \\
Customer's knowledge & .758 & & & \\
\hline Cronbach alpha $=0.78$ & & & & \\
\hline
\end{tabular}

Cronbach alpha $=0.78$

According to the results of Table 5, "Customer value" is the most important component in customer oriented strategy followed by "Customer's knowledge" and "Information services". 


\subsection{The fourth factor: Structure oriented}

Structure oriented is the last important factor with two items summarized in Table 6 . According to the results of Table 6, "Having good relationships with customers" is the most important component in organizational assessment followed by "Security".

\section{Table 6}

The summary of factors associated with targeting appropriate market

\begin{tabular}{lcccc}
\hline \multicolumn{1}{c}{ Option } & Factor & eigenvalues & \% of variance & Accumulated \\
\hline Security & .513 & & & \\
Having good relationships with customers & .849 & 1.535 & 55.155 & 55.155 \\
\hline Cronbach alpha $=0.49$ & & &
\end{tabular}

\section{Conclusion}

We have presented an investigation to find out important factors influencing electronic customer relationship management on reducing customer complaints. The proposed study of this paper has implemented principal component analysis and it detected four factors. The first factor is associated with knowledge management where "Update information" is the most important factor, followed by "Innovation and learning outlook", "Update information", "Digital customer's perception" and "Communication channels". Customer retention is the second important factor and it includes four factors where "trust and support" is number one priority followed by "customer's requirements perception", "Commitment" and "Management of customer information". Customer oriented strategy is another important factor with three items where "Customer value" is the most important component in customer oriented strategy followed by "Customer's knowledge" and "Information services". Finally, structure oriented is the last important factor with two items where "Having good relationships with customers" is the most important component in organizational assessment followed by "Security".

\section{Acknowledgment}

The authors would like to thank the anonymous referees for their construction comments on earlier version of this work.

\section{References}

Aaker, J.L. (2010). Dimensions of brand image. Journal of Marketing Research, 34(3), 347-57.

Ahmad, M. S., \& Rashid, S. (2012). ECRM and customers: a case of Askari Commercial Bank, Pakistan. Business Strategy Series, 13(6), 323-330.

Franco, J. J. (1990). Customer satisfaction: The partnership imperative. Training and Development Journal, 44(7), 80-82.

Hsieh, A.T., \& Li, C.K. (2011). The moderating effect of brand image on public relations perception and customer loyalty. Marketing Intelligence \& Planning, 26(1), 26-42.

Lee-Kelley, L., Gilbert, D., \& Mannicom, R. (2003). How e-CRM can enhance customer loyalty. Marketing Intelligence \& Planning, 21(4), 239-248.

Leuthesser, L., Kohli, C.S. \& Harich, K.R. (2010). Brand image: the halo effect measure. European Journal of Marketing, 29(4), 57-66.

Luck, D., \& Lancaster, G. (2003). E-CRM: customer relationship marketing in the hotel industry. Managerial Auditing Journal, 18(3), 213-231.

Romano Jr, N. C., \& Fjermestad, J. (2003). Electronic commerce customer relationship management: a research agenda. Information Technology and Management, 4(2-3), 233-258. 
Sivaraks, P., Krairit, D., \& Tang, J. (2011). Effects of e-CRM on customer-bank relationship quality and outcomes: The case of Thailand. The Journal of High Technology Management Research, 22(2), 141-157.

Stiglitz, J. E., \& Weiss, A. (1981). Credit rationing in markets with imperfect information. The American economic review, 71(3), 393-410.

Kimiloglu, H., \& Zarali, H. (2009). What signifies success in e-CRM?. Marketing Intelligence \& Planning, 27(2), 246-267. 